\title{
Dybbøl Sogn i Krigsaarene 1848-50.
}

\section{Optegnelser af Pastor $\bar{K}$. K a r ste n s e n. Neddelte af Louis B o b é.}

Nedenstaaende Optegnelser, indførte i Dybbøl Kirkebog (begyndt af David Mourad 1693) ere forfattede af Pastor Kristen Karstensen, føut 25. April 1809 i Kjær, Ulkebøl Sogn, Als, Søn af Boelsmand Karsten Daridsen og Marie Hansdatter. Han blev Student fra Ribe Skole 18:31, Kandidat i Khhvn. 1836, siden Huslærer hos Stiftamtmand Knuth og valgtes 28. April 1839 til Præst i Dybbøl. Gift 31. Maj 1839 med Emma Jensine Kielsen (f. i Kbhvn. 10. Sept. 1811, d. 21. Sept. 1876), Datter af Urmager Jens K. i Randers og Helene Margrethe Lundgreen. 18577, 28. Maj, valgtes han til Provst for Sønderborg Provsti og 6 . Dec. s. A. til Sognepræst i Broager, 1864 blev han afsat af de tyske Civilkommissterer. K. har udgivet en Digtsamling og en Sangbog Gamle og ny Viser til Brug for Skolen og Livet, med sœrligt Hensyn til det danske Folk i Sønderjylland. Han døde 1. November 1882.

\section{Krigen 1848-49.}

Efterat vi fra 1.-25. April harde havt dansk Indqvartering, forst 5te Bataillon under Oberstl. Haxthausen (1.-8. Apr.), dernæst 6te Bataillon under Oberst Hagemann, fik vi den 27. om Aftenen tydsk Indqvartering, først Brunsvigere under Oberst Specht (27. Apr. -3. Mai), dernæst Hannoveranere under Oberst Mar- 
schal (3.-12. Mai), derpaa Oldenborgere og Meklenborgere under Oberst Rantzau (12.-28. Mai), paa hvilken Dag der skete Omqvartering og Oberst Specht kom tilbage som Forpostcommander.

Medens den danske Armee laa nede ved Dannevirke og ventede paa, at Tydskerne ikke skulde komme, kastedes der Skandser (af Ingeniorerne, 6. Bat. og Egnens Beboere) paa Dybbøl Banker, særdeles i Lorens Nielsens og Paul Paulsens Mlark, og alle Hegn omkring Banken og ned efter Færgen til bleve udryddede. Den 25. April om Eftermiddagen var hele Landevejen fra Hvilhoj til Sønderborg Færge opfyldt af danske Tropper, som retirerede over til Als. Skandserne, som ikke vare færdige, bleve rømmede, og der gik kun Patrouille op gjennem Dybbol over Stenderup efter Nybel til. Det forste, som Brunsvigerne foretog sig, var at jævne de danske Skandser, og Befolkningen, som havde hjulpet at kaste dem, blev nu tvungen til at odelægge dem igjen. Brunsvigerne gav sig nu ogsaa til at grave Skandser, flette Fasciner og Skandsekurve. Dette sidste Arbejde foretoges i Degnens Lykke mellem Degneboligen og Jens Alsings Huus. Her og i Peter Kirkmands Mark vesten for Hvilhøjsvejen stod nemlig Artilleriparken.

Kirken blev strax den forste Nat slæbt fuld af Straa, Alterlysene brændte hele Natten, og Straaet blev liggende til fremtidig Afbenyttelse, indtil Hannoveranerne kom, da Kirken paa min Begjæring igjen blev renset og lukket. Der savnedes en Deel Psalmebøger, Daabsklædet, Sølvklokken ved Klingpungen, ellers led Kirken dengang ingen Overlast. Præstegaar- 
den var i Brunsvigernes Tid saa belagt, at vi ikke havde Raadighed over mere end Dagligstuen. Der blev jey ogsaa quasi bevogtet, efterdi man uden Grund havde mig mistænkt for, at jeg skulde skjule en formentlig tilbagebleven dansk Frivillig, min forrige Elev, Grev Adam Knuth. (Der blev i denne Anledning anstillet Huusundersogelse i Nabolaget og i Husene langs med Landevejen. De pirrede og stak omkring med Bajonetterne paa alle mistænkelige Steder. Et Sted - hos Rickel Clausens bag Kirken - randsagede de under Sengen og stodte med Bajonetten mod Noget, som de meente kunde være et Menneske. „Hier ist Gott verd. mich der Kerl", udbrød de - og saa var det en Side Flæsk.)

De Danske begyndte i Begyndelsen af Mai at arbejde paa et Brohoved der, hror $\mathrm{Hans}$ Peter Becks Sted laa, bvilket de afbrændte tilligemed Færgegaarden, Rebslager Petersens Sted samt de andre langs med Vejen liggende Steder, hvoriblandt de til Dyppel hørende Hans Ohlsens, Peter Hansens og Hans Peter Hansens Steder - og idet Tydskerne søgte at forhindre de danske i Brohovedets Anlæggelse, opstod der idelige Sammenstod. Ved disse Sammenstod blev der skudt Ild paa flere Huse, og navnlig afbrændte Peter Jensens Gaard, Maren Horlyks Kaadsted, Jens Jensen Cosmus's Kaadsted, Jacob Dominicussens Sted (Brunhoved) og Lorens Nielsens Gaard. Tydskerne havde deres Forpostleir nede i Dalen ved Østen og forstode herlig at skjule sig for Bomberne under Kæmpehøiene. Den 16. Mai var en af de alvorligste Smaa- 
skjærmydsler; da forsogte Tydskerne at sætte sig fast i Christian Hansens d. Y.'s Gaard, og denne blev nu derfor nedbrudt af de Danske. I den sidste Uge for den 28nde Mai var det temmeligt roligt; vi hørte kun Tydskerne af og til snakke sammen om, at nu havde Danskerne deres Brohoved og Bro færdig, men man lod ikke til at rente dem.

Da hed det pludselig Sondagen d. 28. Mai Kl. henved 12: "Die Dänen landen und ziehen stark hervor". Kl. henved 4 maatte Tydsken trække sig tilbage. Min Karl var med at kjore Saarede. Vognen blev refpireret af 3 Dragoner med blinkende Srierd og var borte i 14 Dage, saa jeg troede at borte var borte. Ogsaa slæbte Tydskerne Boelsmand Lorens Nielsen med sig, om hvem de troede, han havde signaliseret med de Danske, da han just var ude paa Marken og flytte Køer, medens Affæren begyndte. Han kom forst tilhage efter Vaabenstilstandens Afslutning midt i Sept. Af Lig blev der indlagt en dansk Herregaardsskytte (Robertsen) og en hannoveransk Jiegerlieutenant i Dyppel Kirke. De bleve siden bragte til Sonderborg. Ved Retraiten gjennem Dyppel forsogte Tydskerne flere Steder at sætte Ild paa, saaledes hos Skomager Andreas Iversen og Krudenerer Jens Peter Jensen, men Ilden blev slukket.

Den 28. Mai om Aftenen fik vi General Hansen (senere Krigsminister) i Qvarteer. Dagen efter (d. 29de), da det hed, at de Danske bleve drevne tilbage, forte jeg Hustru og Søn samt Tante Wally til Als, til Pastor Krog Meyer i Ulkebølle. Selv vendte jeg Dagen efter tilbage til Dyppel. Den 2. Juni kom Ge- 
neral Schleppegrell i Qvarteer i Præstegaarden, og med Schleppegrells Stab var ogsaa en norsk Frivillig Kandidat Krogh, forhen Redactor af den Constitutionelle. Med ham var jeg den 5te Juni om Formiddagen gaaet til Stenderup for at besoge Nordmanden Baron Lovenskiold, som laa hos Hans Smed. Medens vi gik tilbage derfra, begyndte Kanonerne lystig at spille ved Forposterne. Vi fik travlt med at komme hjem. Jeg fik en Vogn til at holde i Beredskab, og da Skydningerne nærmede sig, satte jcg mig paa tilligemed Onkel Wally (som boede i det saakaldte Enkesæde) og korte ad Sonderborg til. Underveis saae vi allerede flere Vogne med Saarede. Træfningen trak sig nu ind igjennem Dyppel By. Byen blev fuld af Preussere, som brod op og plyndrede allevegne, og spurgte ogsaa efter Præsten "den Verräther, den schwarzen Teufel". Jeg stod imidlertid paa Kirkebakken ved Sonderborg og saa med smertelige Følelser og spæendt Forventning ud over mit kicre Dyppel. Klokken henimod fem Eftermiddag blev Trafningen varm ned efter Stangaard og Suurlykke til; Tysken havde nemlig isinde at omgaae de Danske der, og snart stode Kapt. Otzens og Jac ob Clausens Craarde i Luer (antændte af de Danske), og ikke længe derefter brændte ogsaa Joa chim Carstensens Kaadsted og Claus Clausens Gaard i Østen. Da var det Klokken henred 7 at Garden og 6. Bataillon blev fort i Ilden; de stormede frem imod Dyppel By og dreve Tydskerne ud. Ted Dyppel Kirke harde en Afdeling af 6. Bataillon en haard Dyst. Omegnen af Kirken og Præstegaarden laa bestroet med Lig. $2 \mathrm{Ty}$ - 
skere, den ene en Officer, bleve begravne paa Kirkegaarden tæt førend Tyskerne bleve fordrevne derfra Under Træfningen bleve Beboerne af Dyppel By beordrede til at rykke ud af deres Huse, og Storstedelen af min Menighed flyttede over til Als, deels samme Dag, deels de folgende Dage med Bohave og Kreatur, saa at navnlig Dyppel By fra 5. Juni til Høstens Begyndelse stod øde og forladt. Først i September efter at Vaabenstilstanden omsider var kommen istand, flyttede jeg over. Allerede den 20. Mai havde jeg havt Besøg af Herredsfoged Jacobsen (senere slesvigholstensk Krigsminister) og Regjeringsraad Harbou, som reiste omkring for at forhore, om Præsterne vilde anerkjende den provisoriske Regjering og publicere deres Forordninger. Jeg gav til Srar, at jeg ikke kunde dette, eftersom Kongen (ved Patent af 29. Marts) havde erklæret den provisoriske Regjering for oprørsk og paa det strængeste forbudt Embedsmændene at indlade sig med den eller fremme dens Planer, og jeg desuden allerede havde erklæret mig i samme Retning for den allerhøieste Regjeringscommission, den Gang i Hadersler (d. 21. April). Min Erklæring blev tagen til Protokols og af mig undertegnet. Den 6te October, vor Konges Fødselsdag, kom 2 Dragoner fra const. Herredsfoged Nissen i Broager med nogle Forordninger fra den provisoriske Regjering og forlangte skriftlig Erklæring, om jeg vilde lade dem aflæse i Kirken. Jeg erklærede naturligviis, ifølge det Foregaaende, at jeg ikke kunde det. Ikke længe derefter hørte jeg, at der i tyske Blade berettedes om min Afskedigelse. Dog modtog jeg først $d$. 
29. October det under 13. s. M. af den provisoriske Regjering udfærdigede $D$ im is sions pate $\mathrm{nt}$. Herr const. Justitiarius Henningsen fra Gravensteen kom samme Dag, der var en Sondag ved Kirketid, ridende i Ledtog med 4 Dragoner ind i Præstegaarden og præsenterede mig det bevidste Patent saalydende: „Die provisorische Regierung entlïsst hiedurch den Herrn Pastor Ḱristen Karstensen Ihres Amtes als Prediger in Düppel. Den 13. October 1848. Beseler. F. Reventlau" og udbad sig min "Qvittering" for sammes Modtagelse. Han medbragte tillige et Publicandum uden Navns Cnderskrift, hvori det bekjendtgjordes for Sognet, at jeg af den prorisoriske Regjering var bleven afsat fra mit Embede og at den under 22. s. MI. installerede Fællesregjering havde stadfæstet den provisoriskes Foranstaltninger. Herr Henningsen tillod mig at prædike endnu denne Gang for den forsamlede Menighed. Det af Degnen Herr Jürgensen med megen Iver og Anstriengelse paa den yderste Kirkedor opslagne navnlose Publicandum sad der kun et Par Timers Tid. Hen paa Eftermiddagen flagrede kun enkelte Papirstumper endnu paa Kirkegaarden.

Næste Dags Miiddag (d. 30. October) ankom den som Præst i Dyppel constituerede Candidat Axels e n fra Mjols til Dyppel Præstegaard; og Dagen derpaa flyttede vi til Sonderborg. Mit Tjenestefolk og Kreatur blev tilbage i Dyppel, da Dragonregimentet og Pastor Axelsen tillod det. Under 6te November indgik jeg derpaa med Begjwring til den saakaldte Fællesregjering om at rorde gjenindsat i mit Embede eller eventualiter at vorde bekjendtgjort med Motiverne 
for min Afskedigelse. Menigheden indgik ogsaa under 1. November til Fællesregjeringen med Begjæring om at erholde mig tilbage; men paa begge disse Begjæringer svarede Fallesregjeringen under 22. November med allernaadigst Afslag, erklærede Embedet for „definitiv erledigt" og gjorde Anstalter til dets Besættelse. Da Patronatet ikke vilde anerkjende min Afskedigelse, vilde samme naturligvis heller ikke præsentere til nyt Valg. Regjeringen præsenterede da selv, og det navnlig fornærnte Pastor Axelsen, min fordums gode Ven Pastor Schmidt fra Stenderup og Cand. Godt fra Buskmose; og Menigheden blev opfordret til at $\nabla æ l g e$.

Paa den berammede Valgdag, Fastelarns søndag d. 18. Febr. 1849 modte nu ingen andre Vælgere end Kirkeværgerne, og disse mødte kun for at erklære, at hrerken de eller saa vidt de vidste nogen andre vilde valge. Der blev heller ikke en eneste Valgstemme afgivet; men uagtet denne factiske Protest fra Menighedens Side udnævnte dog den provisoriske Generalsuperintendent Rehhoff paa Regjeringens Vegne Herr Axelsen til Dyppel Menigheds Præst. Menigheden vedblev imidlertid at blive gjenstridig, kun saare faa sogte Kirke og slet ingen Altergang, det blev en gængs Tale, at Pastor Axelsen var nok Kirkens Præst, men Pastor Karstensen var Sognets. Skjondt Passagen i Vinterens Løb, blev besværliggjort, og den politiske Politimester MIudderspach med sin Dragonvagt i og ved Dyppel Molle viste mange tilbage, havde jeg dog hele Vinteren igjennem hartad daglig Huset fuldt af mine kjære Dyplinger. 
$\mathrm{Da}$ den lange ventede 3. A pril omsider kom, og de røde Troier rykkede over, rykkede jeg ogsaa over. Jeg var imidlertid under 28. Marts bleven constitueret som Feltpræst ved den danske Armee. Herr Axelsen havde allerede den 2den April om Aftenen fjernet sig fra Dyppel, men blev den 3die April ved Midllagstide tagen af de danske ved Böjskov og ført til Sonderborg, hvor han tilligemed Pastor Hiort fra Ulderup og Petersen fra Satrup sad nogle Dage og derpaa blev fort til Kjobenhavn. Her blev han tilligemed de Andre frigiven imod, at han skriftlig forpligtede sig til ikke at vilde foretage Noget imod hans retmæssige Landsherre Kong Frederik d. 7de. Glæden i Dyppel ved de danskes Ankomst var stor, men varede desværre kun kort. Skærtorsdag og Langfredag holdt jeg Gudstjeneste i Dyppel, begrov om Lordagen de i Træfningen ved Ulderup (d. 6te April) faldne Danske og Tyske paa Satrup Kirkegaard, og Paaskemorgen (d. 8. April) stod jeg med Armeens Reserve ved Dyppel Molle og ventedo paa Ordre til at gaa frem, men Toget gik tilbage over til Sonderborg. Fra 4.-7. April havde de Danske begyndt at opkaste Skandser paa Dyppel Høider og ryddet Diger og Gjærder fra Hoiderne og ned imod Byen. Disse Værker bleve sidenefter odelagte eller benyttede af Tydskerno.

Den 11 . A pril begyndte nu Tydskerne at indqvartere sig i Dyppel, Ragebel og Staugaard, 150200 Mand i hver Gaard. Først (i Dyppel) Sachsere og Chur Hessere til April Maaneds Udgang; dernæst Brunsvigere og Nassauere i Mai og Juni; siden Ol- 
denborgere (der kom fra Ragebøl og blev der afloste af Brunsvigere) i 3 Uger; derpaa Kongel. Sachsere i 12 Dage - tilsidst Hannoreranere og Prenssere. Den 12 t e A p ril mod Aften foretog de danske (General Bülow) en Recognoscering ned imod Dyppel og ind $\mathbf{i}$ den nedre Deel af Byen. Dette maatte naturligviis hærnes, og Dagen efter paafulgte - „Die Erstïrmung der Djppeler Schanzen" som vel at mærke ikke var besatte. I Nattens Morke listede Tyskerne sig ind paa de danske Forposter, afskare ogsaa en Deel i Lorens Nielsens Huus, som dog snakkede sig fra dem og snege sig ned til Stranden, og i Dagbrækningen stode Tyskerne kun et Par Hundrede Skridt fra det danske Brohoved. Men nu fik de saavel fra de faste Batterier som fra Kanonbaadene saa kraftige Morgenhilsener, at de ansaae det for raadeligst at trække sig tilbage, og for at dække Tilhagegangen og distrahere de faste Batteriers Opmærksomhed, kjørte sachsisk Artillerie op og leirede sig i Suurlykke Egnen mellem Brunhoved og Kapt. Otzens Gaard. Her fik Sachserne 3 Kanoner demonterede, og medens der sloges om dem (de Danske fik de 2) gik der Ild i Dyppel Molle, Lorens Nielsens Huus og Eapt. Otzens Gaard, hrilke 2 sidste Steder saaledes afbrændte anden Gang i denne Krig. Tyskerne mistede denne Dag mange Folk; 7 idetmindste (over hrem et Trækors og en Steen med deres Navn) ligge begravne her paa Kirkegaarden; flere ligge paa Satrup og andre Steder. I Præstegaarden og Kirken laa der stadig indqvarteret en heel Bataillon, circa 1000 Mand. Saavel Kirke som Præstegaarden blev stadig ilde medhandlet, og uagtet Præ- 
sten Axelsen (som fra Kjobenhavn rendte tilbage til Dyppel) var Troppernes Ven, formaaede han ikke at afværge Ødelæggelsen. Særdeles efter Affæren den 17. Maa, Christi Himmelfartsdag, sporede man Vandalisme i K i rken. Orgelet blev aldeles odelagt, Alterbordet sad man og flikkede Sko paa, Maleriet i Alterbladet blev udskaaret og stjaalet, Moses, Christus Figurerne bleve lemlæstede, flere Stolstader bleve odelagte og Dorene i Aflukket bag Alteret borttagne og rimeligviis brændte. Kirken har i denne Tid bogstavelig talt mere været lig en Røverkule end et Bedeluuus! - I P ræs t e g a a r d e n var der ved de tyske Troppers Bortgang kun hele Dore og Vinduer $i$ de 3 af Officerer benyttede Værelser, ellers var Dore og Vinduer itu eller borte, Sengesteder, Skabe, Trappegelænderet og alt andet Brændbart borte og brændt. Væggene, saarel malede som kalkede, vare saa forslaaede og forluggrede, at de nogne Muurstene oreralt tittede frem. Hylder og Beklædning i spisekammeret, Mælkestuen og Kjælderen borte og brændt, kort sagt i hele Hovedbygningen var der næsten intet uden de nogne sorte Steenvægge tilbage. Ogsaa i Ladebygningen saae man dygtige Spor af Odelæggelsens Vederstyggelighed. Næsten alt Trærærk i Lo og Lade, i Stald og paa Stænge var borte og brændt. Ogsaa Haven var forfærdeligt medhandlet: ikke alene at Stakittet ved Indkjorselen og omkring Haven var borte og brændt, men mange Træer vare omhugne eller odelagte, det Hele saa ud som et Vildnis. - Andre Steder her i Sognet gik det dog noget bedre end i Kirken og Præstegaarden, men overalt er der bleven meget odelagt, fornem- 
lig paa Grund af den stadige Brændemangel. Somme Steder (f. Ex. i Ragebol Kro) reve de endogsaa Ladebygninger ned for at faae Brendsel.

Fra Midten af April opforte nu Tyskerne det ene efter det andet Batteri langshen over Kammene paa Dyppel Bakke, forst en stor Skandse med Blokhuus bag ved Lorens Nielsens afbrændte Gaard, dernæst et bag ved den afbrændte Dyppel Molle, siden et ned efter Suurlykke til, ogsaa med et Blokhuus; derpaa kastede man en Skandse mellem det sidste og Lorens Nielsens afbrændte Gaard og dernæst et andet Batteri sønden og osten for samme Gaard og nedenfor den forstopforte Blokhuusskandse, det saakaldte Gefions Batteri, fordi det blev belagt med Kanoner fra Gefion. Ogsaa bag ved Peter Petersen Suurlykkes Gaard begyndte man at opkaste et Batteri. Saa havde man ogsaa ud mod Vimmingbund opkastet adskillige Batterier. Kanonernes Antal vides ikke. Da nu Tyskerne endvidere d. 6. J u n i gav sig ifærd med at opkaste en Lobegrav langs med deres Skandselinie, udspændte der sig en temmelig alvorlig Fægtning, som varede hele Dagen og under hvilken Peter Jensens (2den Gang) og Jens Jensens (Sneis) Gaarde afbrændte, begge skudte i Brand af Tyskerne. Midsommersnat blev der derpaa igjen en lille Fægtning, idet Tyskerne vilde overrumple de danskes Feldvagt ved Jacob Dominicussens Huus, og ved denne Lejlighed blev dette Huus anden Gang afbrændt.

Medens Tyskerne laae her, har de blandt andet ogsaa udgravet og undersøgt Kæmpehøiene (de saakaldte Galgehøie, fordi der i gamle Dage har staact 
en Galge der), men om de lhar fundet noget Kostbart eller Mærkværdigt vides ikke.

Den 21. August bleve Fangerne udvexlede ved Sneiled, dér hvor Apenrader og Gravenstener Landeveiene stode sammen.

En Mængde trefarvede Flag paa høie Stanger flagrede og viftede imidlertid paa Dyppel Skandser. Under rældige Hurraraab og Afsyngning af deres Yndlingssang "Schleswig Holstein“ fore Tyskerne afsted og til deres ventende Venner. De Danske derinod gik meget roligt og ytrede kun nu og da til hinanden: Nu Gudskelor vi slap ud af det Slaveri! Den 9. Sept., en Sondag, afbrændtes Blokhuusene og Barakkerne paa Dyppel Bakke, efterat de slesvig - holstenske Gensdarmer, som efter de udenlandske Troppers Bortnarsch harde bevogtet dem, et Par Dage iforveien vare oploste og forsvundne; og det tilbageblevne Skandsetommer og Riisværk blev bortfort deels af Alsingerne, deels af Omegnens Beboere. Hrem der har sat Ild paa Skandserne vides ikke, men i tyske Aviser har der længe gaaet Røg af den Brand „die Zerstörung der Düppeler Schanzen“.

Saasnart som den ifolge Vaabenstilstandsconventionen (af 10. og 17. Juli) forordnede Bestyrelsescommission for Hertugdommet Slesrig under 25. August var bleven installeret, indgav jeg under 28. s. M. et Andragende til samme Commission om snarest mulig Gjenindsættelse i mit Embede, og Menigheden indgik ogsaa gjennem sine Repræsentanter med Begjæring om at erholde mig tilbage, ligesom ogsaa Patronatet (Grev Arthur Reventlow efter Fuldmagt fra Patronen) 
gjentagne Gange androg paa min Gjenindsættelse. Sagen blev overgiven til Amtmanden over SønderborgNordborg Amt Johannsen til Undersøgelse og træneredes $\mathrm{i}$ en langsommelig Tid.

Endelig den 16. November 1849 modtog jeg (i Sønderborg) en under 15. s. M. udfærdiget Resolution fra Bestyrelses-Commissionen i Flensborg, hrori det gaves mig tilkiende, at Bestyrelses-Commissionen havde besluttet at gjenindsætte mig i mit Embede som Sognepræst for Dyppel, samt at det var overdraget den prov. Superintendent Provst Rehhoff i Apenrade at udføre min Gjenindsættelse, og at Pastor Axelsen saavel som Grevskabets provisoriske Administratorer Feddersen fra Kieding og forhenv. Inspectør Jürgensen paa Sandberg vare underrettede derom. Jeg begav mig herefter strax samme Dags Eftermiddag over til Dyppel og lod ved Kirkeværgerne Pastor Axelsen tilspørge, om han ifølge denne Resolution var villig til at fratræde og overlade mig Embedet. Han erklærede herpaa, at han ikke vilde, og benægtede overhoved at have modtaget nogen herom handlende Underretning. Jeg ventede nu i 8 Dage paa Underretning fra Rehhoff, men da saadan ikke kom, og Rygtet desuden meldte om, at baade han og Axelsen havde protesteret, indgav jeg under 23. s. M. Begjæring til Bestyrelses-Commissionen om, at sammevilde foranstalte det Fornødne til min Gjenindsættelse. Jeg ventede derefter endnu andre 8 Dage paa Svar fra Flensborg, men da der intet kom, tog jeg forst i December selv til Flensborg for at fremskynde Sagen. Her fik jeg det Raad, at jeg skulde flytte over til Dyppel og see at komme 
til Rette med Axelsen, og tillige det Lofte af Kammerherre Tillisch, at jeg i Lobet af de forste Dage skulde høre nærmere fra Flensborg. Den 7. December flyttede jeg da over til Dyppel og drog ind $i$ mit umiddelbar ved Præstegaarden beliggende Huus, samt tilkjendegav Axelsen, at jeg nu var her for at overtage mit Embede. Han var nu ogsaa i Forstningen villig til at fratræde, og jeg beredte mig til at tiltreede mine Funktioner her igjen d. 9. December, som var 2den Sondag i Adrent, men saa kom der Dagen iforveien, d. 8. Decbr., en Skrivelse fra de saakaldte Administratorer for Grerskabet, hvori det paalagdes Axelsen at vedblive at fungere og forbodes Menigheden og dens Forstandere at henvende sig til mig $\mathrm{i}$ Embedsanliggender. Og nu vilde Axelsen naturligviis ikke vige. Da der nu om Sondag Morgen var en usædvanlig Miængde Folk forsamlet ved Kirken i Forventning om, at jeg skulde forrette Gudstjenesten, og adskillige kom ind til mig og anmodede mig om at gaa med dem, som vare komne for at hore mig, ned i Skolen og holde Andagt, da de ellers vilde vendo tilbage med uforrettet Sag, saa var jeg dertil villig, og vi bestemte Tiden til Klokken 11 for ikke at forstyrre Gudstjenesten i Kirken. Men aldrig saasnart havde Pastor Axelsen gjennem Degnen erholdt Kundskab herom, for han indfandt sig hos mig og erklærede, at han ikke tillod saadant og at han vilde gjore alt hvad der stod $\mathrm{i}$ hans Magt for at forhindre og forstyrre vor paatænkte Andagt. For da ikke at volde Skandale opgav jeg det Paatænkte, men forfattede en Beretning om det Forefaldne og reiste Dagen 
efter med Kirkeværger Lorens Lorensen fra Ragebøl og Skoleforstander Jorgen Hansen fra Rarnkoppel til Flensborg for dog omsider at faa Ende paa Sagen. Her fik jeg da udvirket, at der blev givet Commissorium til Amtmand Johannsen paa Nordborg, hrorved det overdroges ham at besørge Axelsens Fjernelse og min Gjenindsættelse, og denne Forretning skete da d. 14. De ce m ber om Formiddagen i mit Huus her ved Præstegaarden. Pastor Axelsen var endnu under denne Forretning i Forstningen passiv Modstander, men da det betydedes ham, at han i Vægringstilfælde vilde blive tvungen, faldt han omsider tilfoie og forlod ogsaa Dagen efter Menigheden. Ved Afregningen med ham maatte jeg forpligte mig til at betale ham for den Deel af Arlingen og Tienden som endnu var forhaanden (circa 230 Traver Korn og 17 Læs Hø) samt for hans Andeel i det løbende Aars Offre og ovrige faste Emolumenter i Alt 450 r. cour.

\section{Notitser om Krigen fortsatte i Dyppel.}

Alle Sognebeboere vare enige om, at det tyske Militær var langt bedre at komme til Rette med i Aaret 1849 end i Aaret 1848. Med Undtagelse af den første Dag, de ind(qvarterede sig her, d. 11. April, sørgede Militæret selv for sin Forpleining. og forlangte kun af Beboerne, at de skulde forsyne dem med Brændsel samt med Mælk og Smør saa meget de kunde, det Sidste dog kun for Betaling. Der fandt vel af og til 
adskillig Uorden Sted, f. Ex. rapsedes der endeel Lam og Hons - (hvorfor der formodentlig i Vinteren 4950 blev saa dyr Tid paa $\mathrm{Eg}$, at man maatte betale Snesen med 10-15 Sk. cour.) - men ellers give Beboerne $\mathrm{i}$ det Hele taget et godt Skudsmaal. Nrsten Ingen af Militæret yttrede nogen Uvillie imod Befolkningen for det danske Sindelags Skyld, og mangen En lod sig endogsaa aabenbar forlyde med, at Folket havde Ret $\mathrm{i}$ at holde paa sin Nationalitet og med sin Konge. Det var ikke med deres gode Villie, at de rare komne her, de var heller end gjerne bleven hjemme at passe deres Dont og sorge for deres Familie, men det var de hoie og lærde Herrer, som harde afstedkommet al den Ulykke og Forvirring baade her og hjemme hos dem. Efter hrad de kunde see, havde Folket det godt her, bedre end de havde det hos dem, og de kunde godt begribe, at man ingen Tyst havde til at indlemmes i Tydskland, efterdi der ikke derved kunde være nogen Fordeel at vinde, men snarere det Modsatte. Saadanne lttringer, som de her anforte, ere efter Beboernes Beretning blevne gjorte af mange, især menige Soldater. Ja mange af de Menige (ogsaa nogle Officerer) skjendte endogsaa paa de saakaldte Hjemmetydskere, som de ansaae for Oplarsmændene til Spektaklen, og viat er det, at de fuldt saa gjerne boede hos danske Folk som hos Hjemmetydskerne, og at danske Folk i Almindelighed harde mindre ranskeligt med at komme ud af det med dem end hine. Noget lignende erfarede jeg ogsaa selv i-1848, da flere Officerer ligefrem udtalte sig i samme Retning for mig personlig, og navnlis aldeles billigede, at jeg ikke 
kunde fole mig bevæget til at anerkjende den provisoriske Regjering og svigte den Kongen givne Troskabsed. Da jeg f. Ex. engang gjennem Generalsuperintendenten Callisen modtog den provisoriske Regjerings Anordning angaaende Kirkebønnen og jeg (i den Hannoveranske Oberst Ranzows og den Meklenborgske Hauptmann Müllers Nærværelse) yttrede, at jeg ikke undlod at bede for Kong Frederik, det maatte saa gaae som det vilde, slog Hauptmann Müller mig paa Skulderen og sagde: „das ist recht, das respectire ich, hol mich der T. . ... Den 5te Juni 1848 var Træfningen, som allerede bemærket, haard i Omegnen af Kirken. Flere Bomber og Granater sloge ned og sprang her, 2 gik igjennem Boelsmand Lorens Hansens Lade, og man ventede, at der var Ild, for det rog og smog forfærdeligt, men det tændte dog ikke. Beboerne skjulte sig deels bag Grundstenene i Husene, deels i Huler i Jorden, Bronde o. s. v. Vore Naboer Jens Alsing og Peter Johannsen havde ogsaa (1849) gravet dem et Hul, hvori de vilde skjule sig, naar der kom noget paa, og - forunderlig nok, inden Aaret var omme, vare de begge i Graven. - Ogsaa 13. April og 17. Mai 1849 naaede Bomberne fra de danske Batterier paa Als tiet herop til Kirken og sprang til Beboernes store Forskrækkelse ved deres Huse, uden dog at anrette nogen Skade.

Af Curiositeter fortælles adskillige. Saaledes havde Strandvagten nede ved Hans Jorgensen Madsens Strand lavet sig et Batteri, bestaaende af en Deel Trumleblokke og andre Runlitykker, som de lagde paa Vognhjul og lode pege u! mod Stranden, og satte 
en med en Stok som Flint bevæbnet Straamand til Vagt derved. Ved Affiren d. 5. Juni 1848 havde Tydskerne barricaderet sig i flere Huse, saaledes i Lien hos Andreas Andresen. Her forefaldt folgende underlige Scene. Medens Husets Folk skjulte sig, det bedste de kunde (Naboen Hans Alexandersens var ogsaa komne derhen med Hest og Koer og laa i Bagerovnen, holdende de uforstaaende Dyr i Reb), og medens nu Militæret havde travlt med at brække Hul i Muren og stikke Bossepiben ud og brænde los, gik der en heel forvoren og ufortrøden Tydsker omkring i Stuen og spilte paa en Fiol - for nu "ging es lustig“ yttrede han, da Folk udtalte deres Forundring over hans besynderlige Adfærd.

Af curiose Misforstaalser fortjene at anfores: Et Steds vilde Tydskerne have en "Hammel". Bonden bragte ham en Vognhammel. Et andet Sted vilde de af Bondemoer laane en "Tasse". Bondemoer lob ud til sin Mand: „Faer! de vil have vor Gasse." "Ja Moer, der er intet andet for, vi maae give dem den." $\mathrm{Og}$ saa fangede de Gassen og bragte den ud til Tydskerne. Ovre i Satrup kom der en tysk Patrouille til en gammel Mand og spurgte efter „Dänen". Manden viste dem hen til "Degnen", som, da han just ikke var nngen „Dänenfreund" over, at man vilde søge danske i hans Huus.

I en af de udgravne Kæmpehoie fandt Tydskerne en Beenrad, som efter hvad Folk mener skal have været Levningerne af en Dreng, der 1761 tjente paa Hans Hansens Sted her rnd Skolen. Den stakkels Dreng fik ot bedrøveligt ", besynderligt Endeligt. En 
Nat kom der nogle Gavtyve ind hos hans Husbond Christen Hansen i det Værelse, hror han laa, og vilde stjæle hans Husbonds Penge. Drengen vaagnede og raalte: „Heida, hvad vil I ved Faers Skaf?** Hvorover Tyvene bleve forskrækkede og fortrak. Nogen Tid efter rar Drengen nede i Lodlykke-Egnen for at rogte sin Husbonds Qvag. Der traf Gartyvene ham, og da der ingen Folk var i Nærheden, tog de oy hængte ham i et Træ. Drengen blev nu anseet som Selvmorder og som saadan begraven under Galgen. En deel Aar derefter blev Anforeren for Tyvebanden greben og hængt i Nybel, og for sin Dod bekjendte han blandt andre Gartyrestreger ogsaa denne, at han for at hæune sig paa Drengen harde gjort det af med ham paa ovenomskrevne Maade.

Nede ved Skandserærkerne, narnlig i Dybbol Osten hos Philip Christensen (nu Hans Petersen), havde Tydskerne forfærdiget en heel Deel smaa nydelige Molleværker, som dreves ikke alene af Vind, men ogsaa af Vand og skulle have været meget snildt og kunstfærdigt indrettede.

Foruden de paa Kirkegaarden begravne tyske Milit rlig vides med Vished, at der ved ovennevnte Hans Petersens Gaard (paa Blegnepletten) ligger (fra 49) en Tydsker. Fra samme Aar og navnlig fra 13de April ligge der 3 Baiere i Bolsmand Nicolai Christensens Toft i Dybbol By, formodentlig fordi de som Katholikker ikke kunde begraves blandt Kjættere paa vor Kirkegaard. Af danske Militærlig vides kun om eet. Det ligger ved Hvilhøi Kro i Eblehaven tæet ved Landeveien og blev begraven der 
efter Affæren den 5. Juni 1848. Formodentlig har han hort til 12. Bataillon, som jo her havde en svær Dyst. Her var det jo ogsaa Morgenstjerne faldt (i et Ledgab lige ved Landevejen).

Overalt malerle Ty dsker n e Fig u r er, Vers, Navne og Inscriptioner. IKirlen staker, foruden en deel Narne oy Datoer, bag paa Alterbladet: "Wer nach Schleswig Holstein ist gewesen, der kennt die Sache schon zu gut. Man nuss mit solchen Schweinen leben, sich auch noch quälen bis auf's Blut.“ Fremdeles: „In diesen Edeln Hallen, kennt man dio Rache nicht, da lass den Mensch verfallen und sïndet ganz fürchterlich." Andre liese: Und "lisst der Mensch was fallen, das stinkt" etc. Paa anden Side (til Hoire) liestes: „Mein Haus ist ein Bethaus; llhr habt's aber zu einer Mördergrube gemacht". Paa Orgelloftet stod skrevet ved Doren (til Venstre): "Kleines (Quartier für 10 Mann, Braunschweiger 2. Bataillon 3. Compagnie. Soldat: Rode, Jochens, Schiitte, Monkemeyer, Bodenhager, Ahrens, Pralle, Schniede, Bank, Peters d. 15. Juli 1849." Formodentlig har man altsaa brækket Orgelet ned for at faa bedre Plads. Et Timeglas, som fur havde været anbragt paa Prædikestolen, men som senere blev borttaget derfra og hensat paa Orgelloftet, have samme 10 Mand forst anbragt over Doren indtil Orgelvarket, formodentliy for at studere Tidens Flygtighed, men siden efter er Timeglasset forsvundet ligesom Orgelet. - I Prestegaarden stod flere Steder paa Vægge og Dore: „Leb wolll, geliebtes Pfarrhaus." I Salen red Indyangen til Hjornestuen: Rantzow potens ille geno- 
ralissimus dormit; ne censes, Sonderburgiam esse delendam? pax est. Auf deutsch: Ranzow, der mächtige Generalissimus schläft. Mleinst du nicht, dass Sonderburg in Flammen gesteckt werden müsse? Aber es ist Friede. Indenfor paa Væggen til Venstre $\mathbf{i}$ den gronne Stue: „wir wünschen unsern Nachfolgern viel Vergnügen, wie wir es genossen haben" - og „Hier ist die schöne Küche Dippel, so dicke Flöhe herum hüpfen.“ Disse Dyr var der ogsaa siden efter en stor Orerflodighed af her i Præstegaarden og overalt i Byen; man kaldte dem tydske Indquvartering. - Ovre paa det nordostre Hjorne af $\mathrm{Enk}$ e h u se t var paa Ydervæggen med megen Kunstfærdighed tegnet (med Kul) en Hest med en Hund paa, efter Sigende tegnet efter Naturen. Der var nemlig en Hund ved Indyvarteringen her, som udmarkede sig ved Færdighed i Ridekunsten. Et Steds her i B yen havde de ogsaa afmalet Degnen Jürgensen og Præsten Axelsen, paa Lvilken sidste Soldaterne $\mathbf{i}$ det Hele ikke vare gode. Han havde nemlig holdt en Feltprædiken for dem engang og deri formanet dem til Orden og sædeligt Forhold, „de maatte vide, at de ikke var komne herind for at plage Folk og odelægge deres Eiendom, de var jo komne for at forsvare Landet." Sligt toge de ham saa ilde op, at de endog havde Lyst til at slaa ham ihjel. Han maatte ogsaa flere Gange fortrække, fordi han ikke kunde hytte sig mellem dem, og ved Bortgangen sloge de næsten alle Ruder i Præstegaarden itu.

Efterat $S k$ and serne vare brændte, blev Værket synet af de graastenske Autoriteter Over- 
inspektor Krogh og const. Justitiarius Henningsen, og det tiloversblevne Træværk blev henført til det saakaldte Sjörsted ved Klodsmager Nicolai Lorensens Huus, og der blev lovet denne Mand $2 \mathrm{Sk}$. cour. om Ugen for at have Opsyn med samme. Efterat vore Krigsfolk d. 16. Juli 1850 varé rykkede over, blev det nævnte Træværk ført til Sønderborg. I Januar 1850 havde vi nogle Dage svenske Dragoner i Indqvartering, da de, formedelst at der var tillagt ved Færgen, ikke kunde komme over til Als. Saa harde vi ogsaa den 9. Juli Nordmænd kommanderede fra Apenrade, som nu droge bort, efter at Freden den 2. Juli var afsluttet, og Landet skulde besættes igjen af Kongens egne Folk. Her i Præstegaarden laa en Kapitain Garben fra Christiania. Den 15. Juli kom der atter Nordmænd til Sognet, den Gang til Ragebol, hvor de forbleve til den $17 \mathrm{de}$, da de, efterat vore Folk vare passerede, begave sig til Sønderborg for at indskibes til Norge. Den 16de tidlig om MIorgen var nemlig den Afdeling af det danske Militær, som laa paa Als, passeret forbi og gaaet til Flensborg. Vi hilste paa adskillige af vore gamle Venner og Bekjendte ude red Boffelkobbel, hvor de i den trykkende Hede hrilede under Træerne og fortærede deres Frokost. 